\title{
Anemhupehins A-C, Podocarpane Diterpenoids from Anemone hupehensis
}

\author{
Xing $\mathrm{Yu}^{1} \cdot$ Kai-Ting Duan ${ }^{1} \cdot$ Zhen-Xiong Wang $^{1} \cdot$ He-Ping Chen ${ }^{1} \cdot$ Xiao-Qing Gan ${ }^{1} \cdot$ Rong Huang $^{1} \cdot$ \\ Zheng-Hui $\mathrm{Li}^{1} \cdot$ Tao Feng $^{1}$ (D) Ji-Kai Liu ${ }^{1}$
}

Received: 22 October 2017/ Accepted: 21 November 2017/Published online: 11 December 2017

(c) The Author(s) 2017. This article is an open access publication

\section{Abstract}

Three new podocarpane diterpenoids, namely anemhupehins A-C (1-3), together with four known analogues (4-7), have been isolated from aerial parts of Anemone hupehensis. Their structures were characterized based on extensive spectroscopic data. Compounds $\mathbf{1}$ and $\mathbf{4}$ showed certain cytotoxicities against human cancer cell lines.

\section{Graphical Abstract}

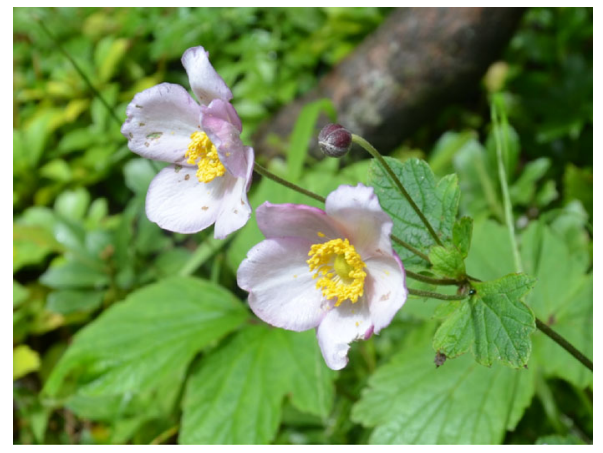<smiles>CC1(C)CCC[C@@]2(C)c3ccc(O)cc3C[C@H](O)[C@@H]12</smiles><smiles>[R]C1CC2C(C)(C)CCC[C@]2(C)c2ccc(O)cc2C1[R]</smiles>

Keywords Anemone hupehensis · Podocarpane diterpenoids · Cytotoxicity

\section{Introduction}

Podocarpane diterpenoids usually possessed a backbone of seventeen carbons arranged in a tricyclohexane system close to abietane and pimarane [1-8]. They do not occur

Electronic supplementary material The online version of this article (https://doi.org/10.1007/s13659-017-0146-6) contains supplementary material, which is available to authorized users.

\section{Tao Feng}

tfeng@mail.scuec.edu.cn

$\triangle$ Ji-Kai Liu

jkliu@mail.kib.ac.cn

1 School of Pharmaceutical Sciences, South-Central University for Nationalities, Wuhan 430074, China extensively in nature but are present in several genera, such as Azadirachta [1-5], Humirianthera [6], Micrandropsis [7], and Podocarpus [8]. Previous studies have disclosed a few biologically active podocarpane molecules, such as 13-hydroxy-8,11,13-podocarpatriene-19-oic acid, a highly fungistatic agent $[9,10]$, and 7-oxo-13-hydroxy-14-amino8,11,13-podocarpatriene, a potent 5-lipoxygenase inhibitor [11].

Anemone hupehensis is a flowering herbaceous perennial in the Ranunculaceae family. It is about one meter high and native in central China. In previous chemical studies on this plant, a few triterpenoids and their saponins were reported [12-15]. In our continuous searching for new and bioactive natural products, we investigated the chemical constituents in aerial parts of A. hupehensis, which resulted 
in the isolation of three new podocarpane diterpenoids, anemhupehins A-C (1-3), as well as four known ones 4-7 (Fig. 1). Compound $\mathbf{4}$ was isolated as a new natural product for the first time. Their structures were established by extensive spectroscopic methods. Compounds $\mathbf{1}$ and 4-7 were evaluated for their cytotoxicities against five human cancer cell lines. We report here the isolation, structure elucidation, and cytotoxicities of these isolates.

\section{Results and Discussion}

Compound 1 was isolated as a colorless oil. The HRESIMS data at $m / z, 283.1668[\mathrm{M}+\mathrm{Na}]^{+}$(calcd for $\mathrm{C}_{17} \mathrm{H}_{24} \mathrm{O}_{2} \mathrm{Na}$ : 283.1669) indicated a molecular formula $\mathrm{C}_{17} \mathrm{H}_{24} \mathrm{O}_{2}$, requiring six degrees of unsaturation. The IR absorption bands at 3438,1608 , and $1480 \mathrm{~cm}^{-1}$ were attributable to hydroxy and phenyl groups. In the ${ }^{1} \mathrm{H}$ NMR spectrum (Table 1), three singlets from at $\delta_{\mathrm{H}} 1.04(3 \mathrm{H}), 1.27(3 \mathrm{H})$, and $1.54(3 \mathrm{H})$ were readily identified signals for three methyls, while three signals at $\delta_{\mathrm{H}} 6.49(1 \mathrm{H}, \mathrm{d}, J=2.8 \mathrm{~Hz}$, $\mathrm{H}-14), 6.67(1 \mathrm{H}, \mathrm{dd}, J=8.6,2.8 \mathrm{~Hz}, \mathrm{H}-12)$, and $7.17(1 \mathrm{H}$, $\mathrm{d}, J=8.6 \mathrm{~Hz}, \mathrm{H}-11$ ) displayed a 1,3,4-trisubstituted aromatic ring. The ${ }^{13} \mathrm{C}$ NMR data, with the aid of DEPT and HSQC spectra, revealed 17 carbon resonances ascribable for three methyl, four methylene, five methine, and five quaternary carbons (Table 1). Analyses of ${ }^{1} \mathrm{H}-{ }^{1} \mathrm{H}$ COSY data disclosed three spin-coupling systems shown in Fig. 2. These data, together with preliminary analyses of HMBC correlations, suggested that 1 possessed a podocarpane skeleton. A phenolic hydroxy group at $\delta_{\mathrm{H}} 5.22(1 \mathrm{H}, \mathrm{s})$ was deduced to be placed at $\mathrm{C}-13$ by analyses of HMBC correlations and NMR data. In addition, another hydroxy group was suggested to be at C-6, as revealed by HMBC correlations from $\delta_{\mathrm{H}} 4.67(1 \mathrm{H}, \mathrm{br} \mathrm{d}, J=5.0 \mathrm{~Hz}, \mathrm{H}-6)$ to $\delta_{\mathrm{C}}$ 53.4 (d, C-5), 41.3 (t, C-7), 34.3 (s, C-4), and $37.2(\mathrm{~s}$, $\mathrm{C}-10$ ), as well as ${ }^{1} \mathrm{H}-{ }^{1} \mathrm{H}$ COSY cross peaks of $\mathrm{H}-6 / \delta_{\mathrm{H}} 1.40$ $\left(1 \mathrm{H}\right.$, br s, H-5) and $\mathrm{H}-6 / \delta_{\mathrm{H}} 3.10$ and $2.85\left(2 \mathrm{H}, \mathrm{H}_{2}-7\right)$. These data elucidated the structure of $\mathbf{1}$ to be 6,13-dihydroxy8,11,13-podocarpatriene. An ROESY experiment revealed the relative configuration of $\mathbf{1}$ (Fig. 2), in which the cross peak of $\mathrm{H}-19 / \mathrm{H}-20$ indicated that $\mathrm{CH}_{3}-19$ and $\mathrm{CH}_{3}-20$ were in the same side ( $\beta$ orientation), while the cross peaks of $\mathrm{H}-18 / \mathrm{H}-5, \mathrm{H}-5 / \mathrm{H}-6$, and $\mathrm{H}-6 / \mathrm{H}-18$ indicated that H-6 should be $\alpha$ oriented. As established by the ROESY data, the energy minimized 3D structure of $\mathbf{1}$ revealed stereoconfiguration of $\mathbf{1}$. A Newman projection of C-5 and C-6 indicated the dihedral angle between H-5 and H-6 to be close to $\theta=90^{\circ}$ (Fig. 2), which resulted in the coupling constants of $J_{5,6}=0 \mathrm{~Hz}$, that is why H-5 presented as a singlet in the ${ }^{1} \mathrm{H}$ NMR spectrum. All these data elucidated the structure of $\mathbf{1}$ to be 6/,13-dihydroxy-8,11,13podocarpatriene, named anemhupehin A.

Compound 2 was isolated as a colorless oil. The HRESIMS established the molecular formula to be $\mathrm{C}_{17} \mathrm{H}_{24} \mathrm{O}_{2}$ on the basis of a molecular ion peak at $m / z 259.1704$ (calcd for $\mathrm{C}_{17} \mathrm{H}_{23} \mathrm{O}_{2}: 259.1704[\mathrm{M}-\mathrm{H}]^{-}$). IR absorption bands (3432, 1612, $1481 \mathrm{~cm}^{-1}$ ) also indicated the presence of hydroxy and phenyl functions. The ${ }^{13} \mathrm{C}$ NMR and DEPT disclosed 17 carbon resonances including three methyl, four methylene, five methine, and five quaternary carbons (Table 1). These data showed similar patterns to those of $\mathbf{1}$. The ${ }^{1} \mathrm{H}-{ }^{1} \mathrm{H}$ COSY cross peak between $\delta_{\mathrm{H}} 4.75(1 \mathrm{H}, \mathrm{m}$, $\mathrm{H}-7$ ) and 2.24/1.64 (each 1H, m, H-6), as well as HMBC correlations from $\mathrm{H}-7$ to $\delta_{\mathrm{C}} 139.5$ (s, C-8) and 30.3 (t, C-6) suggested that a hydroxy should be placed at $\mathrm{C}-7$ in 2 ,
Fig. 1 Structures of compounds 1-7<smiles>C[C@@]1(Br)CCC[C@@]2(C)[C@@H](O)Cc3cc(O)ccc3[C@H]12</smiles><smiles>CC1(C)CCC[C@]2(C)c3ccc(O)cc3[C@@H](O)C[C@@H]12</smiles>

2<smiles>CC1(C)CCC[C@]2(C)c3ccc(O)cc3[C@@H](O)C[C@@H]12</smiles>

3<smiles>[R]C(=P)[C@@]1(C)CCC[C@@]2(C)c3ccc(O)c([R])c3CC[C@@H]12</smiles><smiles>[R]C(=P)[C@@]1(C)CCC[C@@]2(C)c3ccc(O)c([R])c3C(=O)C[C@@H]12</smiles> 
Table $1{ }^{1} \mathrm{H}$ and ${ }^{13} \mathrm{C}$ NMR data for compounds $\mathbf{1}-\mathbf{3}(\delta \text { in ppm, } J \text { in } \mathrm{Hz})^{\mathrm{a}}$

\begin{tabular}{|c|c|c|c|c|c|c|}
\hline \multirow[t]{2}{*}{ No. } & \multicolumn{2}{|l|}{1} & \multicolumn{2}{|l|}{2} & \multicolumn{2}{|l|}{3} \\
\hline & $\delta_{\mathrm{H}}$ & $\delta_{\mathrm{C}}$ & $\delta_{\mathrm{H}}$ & $\delta_{\mathrm{C}}$ & $\delta_{\mathrm{H}}$ & $\delta_{\mathrm{C}}$ \\
\hline \multirow[t]{2}{*}{1} & $2.15(1 \mathrm{H}$, br d, 12.6) & $42.4(\mathrm{t})$ & $2.21(1 \mathrm{H}$, br d, 12.7) & $39.1(\mathrm{t})$ & $2.21(1 \mathrm{H}$, br d, 12.6$)$ & $38.7(t)$ \\
\hline & $1.36(1 \mathrm{H}, \mathrm{m})$ & & $1.31(1 \mathrm{H}, \mathrm{m})$ & & $1.31(1 \mathrm{H}, \mathrm{m})$ & \\
\hline \multirow[t]{2}{*}{2} & $1.83(1 \mathrm{H}, \mathrm{m})$ & $19.7(\mathrm{t})$ & $1.72(1 \mathrm{H}, \mathrm{m})$ & $19.3(\mathrm{t})$ & $1.72(1 \mathrm{H}, \mathrm{m})$ & $19.4(\mathrm{t})$ \\
\hline & $1.60(1 \mathrm{H}, \mathrm{m})$ & & $1.58(1 \mathrm{H}, \mathrm{m})$ & & $1.58(1 \mathrm{H}, \mathrm{m})$ & \\
\hline \multirow[t]{2}{*}{3} & $1.46(1 \mathrm{H}, \mathrm{m})$ & $43.2(t)$ & $1.48(1 \mathrm{H}, \mathrm{m})$ & $41.4(\mathrm{t})$ & $1.48(1 \mathrm{H}, \mathrm{m})$ & $41.6(t)$ \\
\hline & $1.24(1 \mathrm{H}, \mathrm{m})$ & & $1.21(1 \mathrm{H}, \mathrm{m})$ & & $1.21(1 \mathrm{H}, \mathrm{m})$ & \\
\hline 4 & & $34.3(\mathrm{~s})$ & & $33.3(\mathrm{~s})$ & & $33.1(\mathrm{~s})$ \\
\hline 5 & $1.40(1 \mathrm{H}, \mathrm{br} \mathrm{s})$ & $53.4(\mathrm{~d})$ & $1.35(1 \mathrm{H}, \mathrm{dd}, 13.1,3.8)$ & $49.4(d)$ & $1.60(1 \mathrm{H}, \mathrm{m})$ & 44.9 (d) \\
\hline \multirow[t]{2}{*}{6} & $4.67(1 \mathrm{H}, \mathrm{br} d, 5.0)$ & $66.2(d)$ & $2.24(1 \mathrm{H}, \mathrm{m})$ & $30.3(\mathrm{t})$ & $1.98(2 \mathrm{H}, \mathrm{m})$ & $28.7(\mathrm{t})$ \\
\hline & & & $1.64(1 \mathrm{H}, \mathrm{m})$ & & & \\
\hline \multirow[t]{2}{*}{7} & $3.10(1 \mathrm{H}, \mathrm{dd}, 17.4,5.0)$ & $41.3(\mathrm{t})$ & $4.75(1 \mathrm{H}, \mathrm{m})$ & $71.4(\mathrm{~d})$ & $4.76(1 \mathrm{H}, \mathrm{m})$ & $68.4(d)$ \\
\hline & $2.85(1 \mathrm{H}, \mathrm{d}, 17.4)$ & & & & & \\
\hline 8 & & $133.1(\mathrm{~s})$ & & $139.5(\mathrm{~s})$ & & $137.6(\mathrm{~s})$ \\
\hline 9 & & $141.3(\mathrm{~s})$ & & $142.5(\mathrm{~s})$ & & $142.6(\mathrm{~s})$ \\
\hline 10 & & $37.2(\mathrm{~s})$ & & $38.1(\mathrm{~s})$ & & $37.7(\mathrm{~s})$ \\
\hline 11 & $7.17(1 \mathrm{H}, \mathrm{d}, 8.6)$ & $126.7(\mathrm{~d})$ & $7.10(1 \mathrm{H}, \mathrm{d}, 8.7)$ & $126.1(\mathrm{~d})$ & $7.14(1 \mathrm{H}, \mathrm{d}, 8.4)$ & $126.1(\mathrm{~d})$ \\
\hline 12 & $6.67(1 \mathrm{H}, \mathrm{dd}, 8.6,2.8)$ & $113.9(d)$ & $6.72(1 \mathrm{H}, \mathrm{dd}, 8.7,2.7)$ & $115.1(\mathrm{~d})$ & $6.74(1 \mathrm{H}, \mathrm{dd}, 8.4,2.6)$ & $116.0(\mathrm{~d})$ \\
\hline 13 & & $153.3(\mathrm{~s})$ & & $153.7(\mathrm{~s})$ & & $153.7(\mathrm{~s})$ \\
\hline 14 & $6.49(1 \mathrm{H}, \mathrm{d}, 2.8)$ & $115.5(\mathrm{~d})$ & $6.99(1 \mathrm{H}, \mathrm{d}, 2.7)$ & $113.3(\mathrm{~d})$ & $6.82(1 \mathrm{H}, \mathrm{d}, 2.6)$ & $116.0(d)$ \\
\hline 18 & $1.04(3 \mathrm{H}, \mathrm{s})$ & $33.9(q)$ & $0.95(3 \mathrm{H}, \mathrm{s})$ & $33.2(q)$ & $0.97(3 \mathrm{H}, \mathrm{s})$ & $33.3(\mathrm{q})$ \\
\hline 19 & $1.27(3 \mathrm{H}, \mathrm{s})$ & $23.9(q)$ & $0.92(3 \mathrm{H}, \mathrm{s})$ & $21.7(q)$ & $0.92(3 \mathrm{H}, \mathrm{s})$ & $21.7(q)$ \\
\hline 20 & $1.54(3 \mathrm{H}, \mathrm{s})$ & $27.3(q)$ & $1.22(3 \mathrm{H}, \mathrm{s})$ & $25.6(q)$ & $1.10(3 \mathrm{H}, \mathrm{s})$ & $24.2(q)$ \\
\hline $\mathrm{OH}$ & $5.22(1 \mathrm{H}$, br s $)$ & & $4.96(1 \mathrm{H}, \mathrm{br} \mathrm{s})$ & & $5.37(1 \mathrm{H}$, br s $)$ & \\
\hline
\end{tabular}

The assignments were based on DEPT, ${ }^{1} \mathrm{H}-{ }^{1} \mathrm{H}$ COSY, HSQC, and HMBC experiments ${ }^{\mathrm{a}}$ Data $(\delta)$ were measured in $\mathrm{CDCl}_{3}$

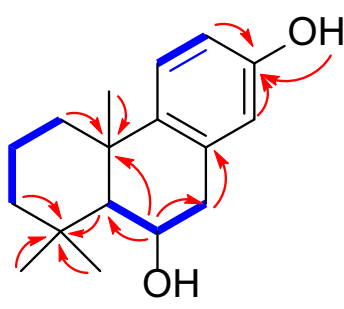

${ }^{1} \mathrm{H}-{ }^{-1} \mathrm{H}$ COSY

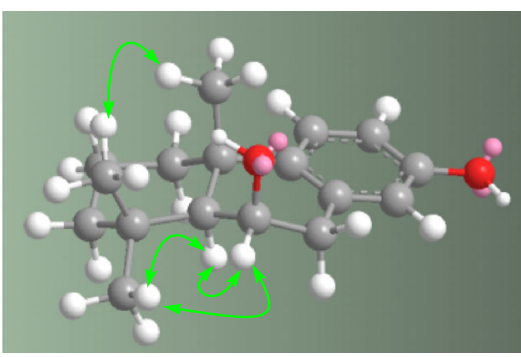

$\mathrm{HMBC}$

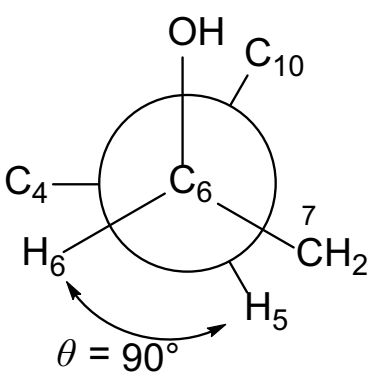

Newman projection

Fig. 2 Key 2D NMR correlations of $\mathbf{1}$ and stereoconfiguration analyses

rather than at C-6 in 1. Detailed analyses of 2D NMR data indicated that the other parts of $\mathbf{2}$ were the same to those of 1. In the ROESY spectrum, cross peaks of $\mathrm{H}-5 / \mathrm{H}-7$ suggested that $\mathrm{OH}-7$ should be $\beta$ oriented. Therefore, compound 2 was elucidated as 7 $\beta, 13$-dihydroxy-8,11,13podocarpatriene, named anemhupehin $\mathrm{B}$.
Compound $\mathbf{3}$ was initially isolated as a mixture with $\mathbf{2}$. A further isolation of this mixture only obtained pure compound $\mathbf{2}$, while the amount of compound $\mathbf{3}$ is too less to obtain the clear NMR spectra. However, careful analyses of MS data of $\mathbf{3}$ and NMR spectra of the mixture (see Supporting Information), with the aid of NMR spectrum of $\mathbf{2}$, can unambiguously elucidate the structure of $\mathbf{3}$. The 
HRESIMS of $\mathbf{3}$ displayed a molecular ion peak at $\mathrm{m} / \mathrm{z}$ 259.1704 (calcd for $\mathrm{C}_{17} \mathrm{H}_{23} \mathrm{O}_{2}: 259.1704[\mathrm{M}-\mathrm{H}]^{-}$), revealed the molecular formula $\mathrm{C}_{17} \mathrm{H}_{24} \mathrm{O}_{2}$, the same to that of 2. The ${ }^{13} \mathrm{C}$ NMR data also showed good agreements with those of 2 . Analyses of $1 \mathrm{D}$ and $2 \mathrm{D}$ NMR data suggested that compound $\mathbf{3}$ should have the same planar structure to that of $\mathbf{1}$. However, the ${ }^{13} \mathrm{C}$ NMR shift of C-7 at $\delta_{\mathrm{C}} 68.4$ in $\mathbf{3}$ was significantly different from that in $\mathbf{2}$, indicating that compound $\mathbf{3}$ might be an epimer of $\mathbf{2}$. In the ROESY spectrum of the mixture, the cross peaks of $19 / \mathrm{H}-$ 20 and $\mathrm{H}-18 / \mathrm{H}-5$ suggested that $\mathrm{C}-5$ and $\mathrm{C}-10$ possessed the same configurations to those in compounds 2 . Therefore, compound $\mathbf{3}$ was determined to be 7 -epimer of $\mathbf{2}$. The 3D structure analyses of $\mathbf{3}$ and $\mathbf{2}$ also supported that $\mathrm{OH}-7$ in $\mathbf{3}$ should be $\alpha$ oriented. Therefore, compound $\mathbf{3}$ was elucidated as 7 $\alpha, 13$-dihydroxy-8,11,13-podocarpatriene, named anemhupehin $\mathrm{C}$.

Four known analogues were identified as 13,14-dihydroxy-8,11,13-podocarpatriene (4) [16], 13-hydroxy8,11,13-podocarpatriene (5) [17], 13,14-dihydroxy-7-oxo8,11,13-podocarpatriene (6) [17], and 13-hydroxy-7-oxo8,11,13-podocarpatriene (7) [18]. Compound 4 was isolated as a natural product for the first time.

Compounds 1 and 4-7 were evaluated for their cytotoxicities to five human cancer cell lines. As a result, compounds $\mathbf{1}$ and $\mathbf{4}$ showed moderate activities as shown in Table 2. The other compounds were inactive to cancer cell lines $\left(\mathrm{IC}_{50}>40 \mu \mathrm{M}\right)$.

\section{Experimental}

\subsection{General Experimental Procedures}

Optical rotations were measured on a Jasco-P-1020 polarimeter. IR spectra were obtained using a Bruker Tensor 27 FT-IR spectrometer with $\mathrm{KBr}$ pellets. NMR spectra were acquired with a Bruker DRX-600 with tetramethylsilane (TMS) used as an internal standard. HRESIMS were recorded on an API QSTAR Pulsar spectrometer. Silica gel (200-300 mesh), Sephadex LH-20 and RP-18 gel $(20-45 \mu \mathrm{m})$ were used for column chromatography (CC). Medium pressure liquid chromatography (MPLC) was performed on a Biotage system. Preparative

Table 2 Cytotoxicities of compounds 1 and $\mathbf{4}\left(\mathrm{IC}_{50}, \mu \mathrm{M}\right)$

\begin{tabular}{llllll}
\hline Entry & HL-60 & SMMC-7721 & A-549 & MCF-7 & SW480 \\
\hline $\mathbf{1}$ & $>40$ & 33.8 & $>40$ & 28.8 & 13.2 \\
$\mathbf{4}$ & 16.8 & 22.7 & $>40$ & 12.2 & 14.1 \\
Cisplatin & 4.4 & 12.4 & 16.4 & 17.1 & 12.8 \\
\hline
\end{tabular}

high performance liquid chromatography (prep-HPLC) was performed on an Agilent 1260 liquid chromatography system equipped with Zorbax SB-C18 columns (5 $\mu \mathrm{m}$, $9.4 \mathrm{~mm} \times 150 \mathrm{~mm}$ or $21.2 \mathrm{~mm} \times 150 \mathrm{~mm}$ ) and a DAD detector. Fractions were monitored by TLC and spots were visualized by heating silica gel plates immersed in $\mathrm{H}_{2} \mathrm{SO}_{4}$ in $\mathrm{EtOH}$, in combination with the Agilent 1200 series HPLC system (Eclipse XDB-C18 column, $5 \mu \mathrm{m}$, $4.6 \times 150 \mathrm{~mm})$.

\subsection{Plant Material}

Aerial parts of A. hupehensis were collected from ShenLongJia of Hubei province, central China in September 2016 and identified by Prof. Ming-Qing Pan of Wuhan University. A specimen (No. COP-HF20160912.4) was deposited at South-Central University for Nationalities.

\subsection{Extraction and Isolation}

The air dried sample of $A$. hupehensis $(8 \mathrm{~kg})$ were extracted with methanol $(24 \mathrm{~h} \times 3)$ to afford an extract. The extract was partitioned with water and EtOAc (1:1). The extract of EtOAc lay (202 g) was subjected to silica gel $\mathrm{CC}$ using $\mathrm{CHCl}_{3}-\mathrm{MeOH}$ (from 1:0 to 0:1) to give eight fractions $(\mathrm{A}-\mathrm{H})$. Fraction $\mathrm{C}(23.8 \mathrm{~g})$ was separated by MPLC with gradient mixture of $\mathrm{MeOH}$ and $\mathrm{H}_{2} \mathrm{O}$ (20:80-100:0, v/v) to afford ten sub-fractions (C1-C10). Fraction C2 (500 mg) was isolated by silica gel CC using petroleum ether/ $\mathrm{Me}_{2} \mathrm{CO}(6: 1)$ to afford several subfractions, and compound 6 (13 $\mathrm{mg})$ crystallized from one subfraction. Fraction C4 (280 mg) was purified by Sephadex $\mathrm{LH}-20(\mathrm{MeOH})$ to give compounds 1 (7.2 $\mathrm{mg})$ and 4 (8.6 mg). Compounds $\mathbf{2}$ and $\mathbf{3}$ was initially isolated as a mixture $(2.8 \mathrm{mg})$ as obtained from fraction C5 (120 mg) by silica gel CC, and was re-purified by HPLC $\left(\mathrm{MeCN}: \mathrm{H}_{2} \mathrm{O}\right.$ $(\mathrm{v} / \mathrm{v})$ from $2: 8$ to $4: 6$ in $25 \mathrm{~min}$ ) to afford pure compounds $2(1.1 \mathrm{mg}$ ) and 3 (less than $0.5 \mathrm{mg})$. Fraction C6 (300 mg) was isolated by Sephadex LH-20 (MeOH) and then purified by HPLC (MeCN: $\mathrm{H}_{2} \mathrm{O}(\mathrm{v} / \mathrm{v})$ from 3:7 to $4: 6$ in $\left.25 \mathrm{~min}\right)$ to afford 5 (6.8 $\mathrm{mg})$ and 7 (3.4 $\mathrm{mg})$.

\subsubsection{Anemhupehin A (1)}

Colorless oil, $[\alpha]_{\mathrm{D}}^{22}+17.6(c \quad 0.18 \mathrm{MeOH})$; IR (KBr) $v_{\max }$ 3443, 3438, 2928, 1624, 1608, 1480, 1367, 1201, $862 \mathrm{~cm}^{-1}$; for ${ }^{1} \mathrm{H}(600 \mathrm{MHz})$ and ${ }^{13} \mathrm{C}$ NMR $(150 \mathrm{MHz})$ data $\left(\mathrm{CDCl}_{3}\right)$, see Table 1; HRESIMS: $m / z 283.1668$ (calcd for $\mathrm{C}_{17} \mathrm{H}_{24} \mathrm{O}_{2} \mathrm{Na}$, [M $\left.\left.+\mathrm{Na}\right]^{+}, 283.1669\right)$. 


\subsubsection{Anemhupehin B (2)}

Colorless oil, $[\alpha]_{\mathrm{D}}^{22}+12.7(c 0.08 \mathrm{MeOH})$; IR $(\mathrm{KBr}) v_{\max }$ $3441,3432,2926,1612,1481,1381,1211,882 \mathrm{~cm}^{-1}$; for ${ }^{1} \mathrm{H}(600 \mathrm{MHz})$ and ${ }^{13} \mathrm{C}$ NMR $(150 \mathrm{MHz})$ data $\left(\mathrm{CDCl}_{3}\right)$, see Table 1; HRESIMS: $m / z, 259.1704$ (calcd for $\mathrm{C}_{17} \mathrm{H}_{23} \mathrm{O}_{2}$, $\left.[\mathrm{M}-\mathrm{H}]^{-}, 259.1704\right)$.

\subsubsection{Anemhupehin C (3)}

Colorless oil, $[\alpha]_{\mathrm{D}}^{22}+8.7($ c $0.02 \mathrm{MeOH})$; for ${ }^{1} \mathrm{H}(600 \mathrm{MHz})$ and ${ }^{13} \mathrm{C}$ NMR $(150 \mathrm{MHz})$ data $\left(\mathrm{CDCl}_{3}\right)$, see Table 1 ; HRESIMS: $m / z, 259.1704$ (calcd for $\mathrm{C}_{17} \mathrm{H}_{23} \mathrm{O}_{2},[\mathrm{M}-\mathrm{H}]^{-}$, 259.1704).

\subsection{Cytotoxicity Assay}

Human myeloid leukemia HL-60, hepatocellular carcinoma SMMC-7721, lung cancer A-549 cells, breast cancer MCF-7 and colon cancer SW480 cell lines were used in the cytoxic assay. All cell lines were cultured in RPMI-1640 or DMEM medium (Hyclone, USA), supplemented with $10 \%$ fetal bovine serum (Hyclone, USA) in $5 \% \mathrm{CO}_{2}$ at $37{ }^{\circ} \mathrm{C}$. The cytotoxicity assay was performed according to the MTT (3-(4,5-dimethylthiazol-2-yl)-2,5-diphenyl tetrazolium bromide) method in 96-well microplates [19]. Cisplatin was used as a positive control.

Acknowledgements This work was financially supported by National Natural Science Foundation of China (81561148013, 81373289, and 21502239), the Key Projects of Technological Innovation of Hubei Province (No. 2016ACA138), and the Fundamental Research Funds for the Central University, South-Central University for Nationalities (CZZ17006, CSP17061). The authors thank Analytical \& Measuring Centre, South-Central University for Nationalities, for the NMR measurements.

\section{Compliance with Ethical Standards}

Conflict of interest The authors declare no conflict of interest.
Open Access This article is distributed under the terms of the Creative Commons Attribution 4.0 International License (http://creative commons.org/licenses/by/4.0/), which permits unrestricted use, distribution, and reproduction in any medium, provided you give appropriate credit to the original author(s) and the source, provide a link to the Creative Commons license, and indicate if changes were made.

\section{References}

1. P.L. Majumder, D.C. Maiti, W. Kraus, M. Bokel, Phytochemistry 26, 3021-3023 (1987)

2. I. Ara, B.S. Siddiqui, S. Faigi, S. Siddiqui, Phytochemistry 27, 1801-1804 (1988)

3. S. Siddiqui, I. Ara, S. Faigi, T. Mahmood, B.S. Siddiqui, Phytochemistry 27, 3903-3907 (1988)

4. I. Ara, B.S. Siddiqui, S. Faigi, S. Siddiqui, J. Nat. Prod. 51, 1054-1061 (1988)

5. I. Ara, B.S. Siddiqui, S. Faigi, S. Siddiqui, J. Nat. Prod. 20, 816-820 (1990)

6. M.D. Zoghbl, N.F. Roque, H.E. Gottlieb, Phytochemistry 20, 1669-1673 (1981)

7. M.A.D. Alvarenga, J.D. Silva, H.E. Gottlieb, O.R. Gottlieb, Phytochemistry 20, 1159-1163 (1981)

8. R.C. Cambie, L.M. Mander, Tetrahedron 18, 465-475 (1962)

9. R.A. Franich, P.D. Gadgil, L. Shain, Physiol. Plant. Pathol. 23, 183-195 (1983)

10. H.T. Cheung, T. Miyase, M.P. Lenguyen, M.A. Smal, Tetrahedron 49, 7903-7915 (1993)

11. T. Oishi, Y. Otsuka, T. Limori, Y. Sawada, S. Ochi, Patent JP 91-36296 (1992)

12. M. Wang, F. Wu, Y. Chen, Phytochemistry 34, 1395-1397 (1993)

13. M.K. Wang, F.E. Wu, Y.Z. Chen, Phytochemistry 44, 333-335 (1996)

14. A. Yokosuka, T. Sano, K. Hashimoto, H. Sakagami, Y. Mimaki, Chem. Pharm. Bull. 57, 1425-1430 (2009)

15. F. Li, X. Liu, M. Tang, B. Chen, L. Ding, L. Chen, M. Wang, Carbohydr. Res. 353, 49-56 (2012)

16. G.B. Evans, R.H. Furneaux, M.B. Gravestock, G.P. Lynch, G.K. Scott, Bioorg. Med. Chem. 7, 1953-1964 (1999)

17. Y.H. Kuo, C.I. Chang, C.K. Lee, Chem. Pharm. Bull. 48, 597-599 (2000)

18. C.T.A. Minh, N.M. Khoi, P.T. Thuong, I.H. Hwang, D.W. Kim, M.K. Na, Biochem. Syst. Ecol. 44, 270-274 (2012)

19. T.J. Mosmann, J. Immunol. Methods 65, 55-63 (1983) 